\title{
Development of Load Characteristic of Main Engine and Its PLC Compatible Preparation in Cooperation with Water Brake as Generator
}

\author{
Matthias Markert ${ }^{1}$, Hartmut Schmidt ${ }^{2}$, Muhammad Faiz Rifqi Ardyatama ${ }^{3}$
}

\begin{abstract}
In the engine industry, dynamometer is used in conjunction with a power source and instrumentation to determine engine HP, Torque, and Efficiency ratings with a high degree of accuracy. Water brake are proven durable designs which use water flowing through the absorber to create a load on the engine. Only the amount of water necessary to provide the load is required. Precise load control of the dynamometer is as simple as increasing or decreasing water volume flowing through the dynamometer absorption body. The controls ensure engine load remains stable throughout the duration of the test cycle. Torque, horsepower, RPM, and water temperature are displayed on highly accurate digital instrumentation. Computers can perform both sequential control and feedback control, and typically a single computer will do both in an industrial application. Programmable logic controllers are a type of special purpose microprocessor that replaced many hardware components such as timers and drum sequencers used in relay logic type systems. They can also analyze data and create real time graphical displays for operators and run reports for operators, engineers and management. Industrial control systems are usually used in all over in control system. A distributed control system refers to a control system in which the controllers are spread throughout the system and connect by networks. Smaller automation applications can be implemented with programmable logic controllers. This research basically is about designing a programmable logic controller compatible for dynamometer to control speed, power and torque of main engine. To test engine performance in the laboratory, the engine is coupled to a dynamometer. In this research dynamometer are used to measure speed, power and torque. One of the most essential role of the control engineer is tuning of controller. Hence the performance of the calculated controller parameters depends on the correctness of the identified process model developed from engine behavior.
\end{abstract}

Keywords-generator, load characteristics, main engine, PLC, water brake

\section{INTRODUCTION}

$\mathrm{W}$ ater brake dynamometer can be used in any application where a load brake is required on a rotational load. In the engine industry, dynamometer used in conjunction with a power source and instrumentation to determine engine HP, Torque, and Efficiency ratings with a high degree of accuracy [1-6].

Other characteristics of an operating engine can only be determined with a dynamometer, such as: heat rise, bearing performance, winding design rating, insulation integrity, harmonic distortion, rotor bar lo oneness, DC brush contact, variable frequency drive influences, and engine slip characteristics. A properly operating engine should last longer, run better, and cost less to maintain [6-7].

Dynamometer (water brake) utilize water flow proportional to the applied load to create resistance to the engine. A controlled flow of water through the inlet manifold is directed at the center of the rotor in each absorption section. This water is then expelled towards the outside of the dynamometer body by centrifugal force [6-8].

Matthias Markert, Maritime Department, Hochschule Wismar, Rostock, Germany, Email: matthias.markert@hs-wismar.de

Hartmut Schmidt, Maritime Department, Hochschule Wismar, Rostock, Germany, Email: hartmut.schmidt@hs-wismar.de

Muhammad Faiz Rifqi Ardyatama, Department of Marine Engineering, Institut Teknologi Sepuluh Nopember, Campus ITS Sukolilo-Surabaya 60111, Indonesia, Email: -
As it is directed outward, the water is accelerated into pockets on the stationary stator plates where it is decelerated. This continuous acceleration/deceleration of the water creates the applied load to the engine. Through this transfer of energy, the water is heated and discharged [8-10].

Dynamometer (water brake) are proven durable designs which use water flowing through the absorber to create a load on the engine. Only the amount of water necessary to provide the load is required. Sufficient internal clearance within the absorber body eliminates the need for cooling water and thermal overload protection, unlike typical industry offerings. If the water overheats under test and vaporizes, then the dynamometer simply stops absorbing the load [7-9].

Precise load control of the dynamometer is as simple as increasing or decreasing water volume flowing through the dynamometer absorption body. The controls ensure engine load remains stable throughout the duration of the test cycle. Torque, horsepower, RPM, and water temperature are displayed on highly accurate digital instrumentation [1-12]

\section{RESEARCH METHODOLOGY}

\section{A. Statement of Problems}

This stage is an early stage to construct the research. In this stage, questions and problems are being prepared specifically in order to determine the specific objectives of this research. The content of the research is to overcome the statement of the problems mentioned earlier and it will be done by collect some information 
about the problems. Therefore, the purpose of this research can be understood in this stage.

\section{B. Literature Study}

Right after the problems is raised, a literature study is performed. In this stage, literature will be used to connect the problems with existing theories and facts from various sources. Since this research is an implementation of many aspects discipline, various literature topics is required to be constructed into one project. The study of literature is done by reading papers, journals, research, media and literature books that relates and able to support this research.

\section{Collecting Data}

After literature study which support the research has been done, collecting data is being performed. Data collection is done by gather information to develop the analysis.

\section{System Analysis}

After the required data has been collected, the next step is to analyzing system used. At this stage is certain that the system and components is a compatible or not. Because if the system and component not compatible, so the system must be repaired.

\section{E. Inputting Variation Data}

After the system is declared safe and functioning properly then able to use the system. From various sources has been obtained then made a wide variety of data to be entered into the software PLC as the beginning of the experiment.

\section{F. PLC Processing}

At this stage, the time from a wide variety of data inputted before, then the software will process the data automatically. Some variation of these data will generate a wide variety of different results. We can observe the difference.

\section{G. Collect Outputting Data}

This is the last stage of the experiment. From a variety of different results, we can collect the results from such data. We collect the data that can be used and discard the data that can't be used. If the data can't be used then testing can be done again.

\section{H. Conclusion \& Recommendation}

After obtaining all the necessary data, then we can process and analyze the data. Than processed products and analysis of these data we can conclude from the results of this experiment. Conclusion of this experiment can produce a suggestion that can be useful to improve the situation if any deficiencies.

Testing of engine performance is often important in the development of engine. Many parameters affect an engine's performance: the basic engine design, speed, torque \& power. Proper tuning of an engine requires careful measurements of power, torque and speed as a function of throttle position.

In this study, measurement of speed, power and torque as function of throttle position is required. In above system overview testing of engine performance in the laboratory shows that the engine under test is coupled to a dynamometer. The dynamometer, which provides a load to the engine, can be easily controlled to allow testing under a wide range of speeds and torque.

If load increases engine speed decreases \& torque increases because load cell is kept inside dynamometer. Three sensors are used such as throttle position sensor, magnetic pick up tachometer as speed sensor, load cell for torque measurement.

An integral component of a dynamometer is its data acquisition system. The system is typically comprised of two units, a Commander and Workstation, connected by an Ethernet cable. The Workstation operates the precision load and throttle control systems, collects the data, and sends it to the Commander to be processed, stored and analyzed shown in figure 1.

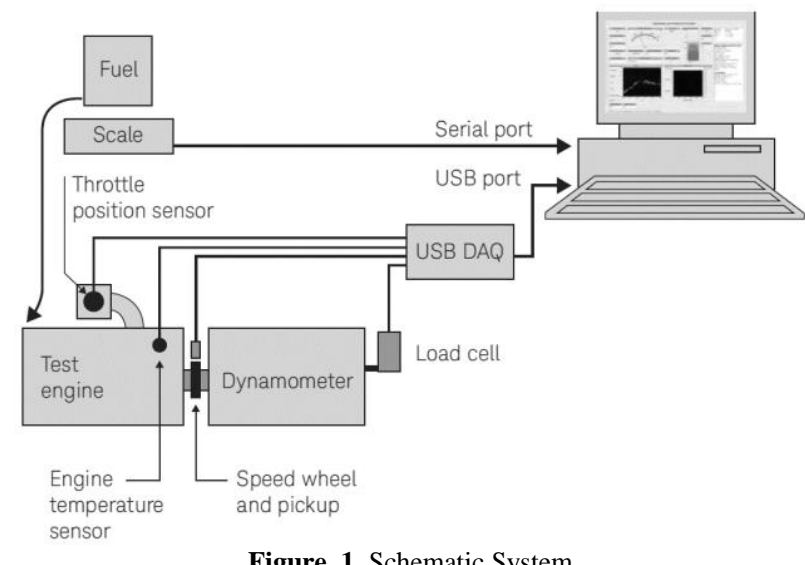

The basic operation of a water brake dyno uses the principle of viscous coupling. The output shaft of the engine is coupled to a fan that spins inside a concentric housing. While the engine is running, the housing is filled with a controlled amount of water. The more water that is allowed into the housing, the more load the engine will feel (see figure 2).
As the fan spins through the water, the water is whipped around as well. Newtons 3rd Law says that the water will push on by the housing with the equal and opposite force that the fan is pushing on the water. In this case, the shear forces in the water are acting tangential to the housing radius. There is a load cell at a measured distance from the center of the housing. The load cell is 
also oriented perpendicular to the arm extending from the housing. The torque output of the engine is just the force measured at the load cell multiplied by the distance to where the extended arm and load cell connect.

There is also a data acquisition system on the dyno. The data acquisition systems sensors measure force, input shaft RPM, oil pressure, fuel pressure, fuel flow rate. From these sensors, math channels are set up to calculate whatever you want. A few of the most useful things this system calculates are torque, horsepower, and brake specific fuel consumption. Horsepower is just a function of torque and RPM. This is realized in the water brake system in laboratory building of the Maritime Department of Hochschule Wismar.

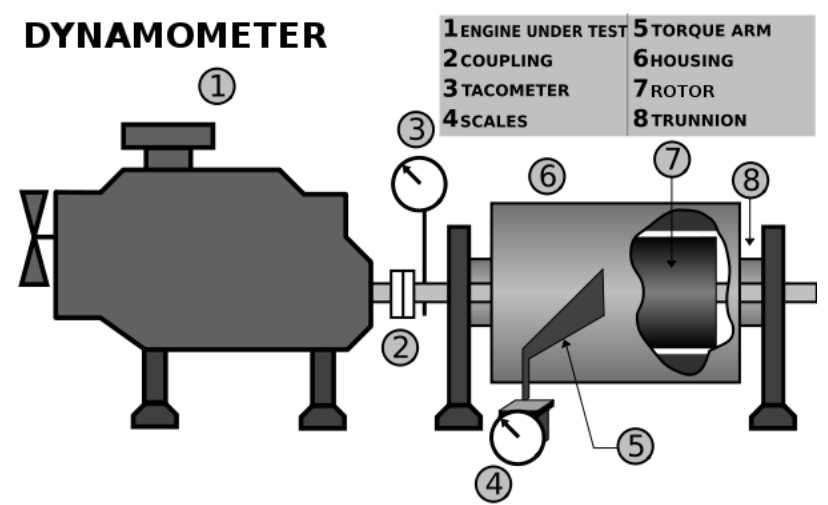

Figure. 2. Water Brake

If the units are in Newton-meters and shaft speed (S) is measured in radians per second, then the shaft power or break power $(\mathrm{P})$ of the engine can be calculated by multiplying the speed and the torque $(\mathrm{T})$ :

$$
\mathrm{P}=\mathrm{T} \times \mathrm{S}
$$

In Speed Controlled mode a set speed is given to the controller, if the measured speed of the shaft is less than that of the set speed, the load is decreased. If the measured speed of the shaft is greater than that of the set speed, then the load is increased. Assuming the engine has sufficient torque to attain the set speed, this will maintain a constant speed of engine which is under test. Where throttle valve is $100 \%$ open to test speed parameter of engine, by varying load \& keeping speed constant of main engine.

In Load Controlled mode a set load is given to the controller. If the measured load on the dynamometer is greater than that of the set load, the load is decreased. If the measured load on the dynamometer is less than that of the set load, then the load is increased. Assuming the engine has sufficient torque to attain the set load, this will maintain a constant load while the speed varies.
An Engine is a device which transforms chemical energy of fuel into thermal energy \& uses thermal energy to produce mechanical work. Engine normally converts thermal energy in to mechanical work. This research shown testing of engine using dynamometer. An engine dyno calculates power output directly by measuring the force (torque) required to hold a spinning engine at a set speed (rpm) means through engine behavior as shown in below table I here two quantities are under controlled such as torque \& speed [7-8].

\section{RESULT AND DISCUSSION}

\section{A. Collect Data}

Before made some analysis for this research, I collect all of the data from Laboratory Building (House 5) of the Maritime Department of Hochschule Wismar. I got the main engine data (see table 1), water brake data (see table 2), main engine and water brake performance (see figure 3) from Mr. Hartmut Schmidt. This data as a guide to take the next step to make some calculation and PLC programming.

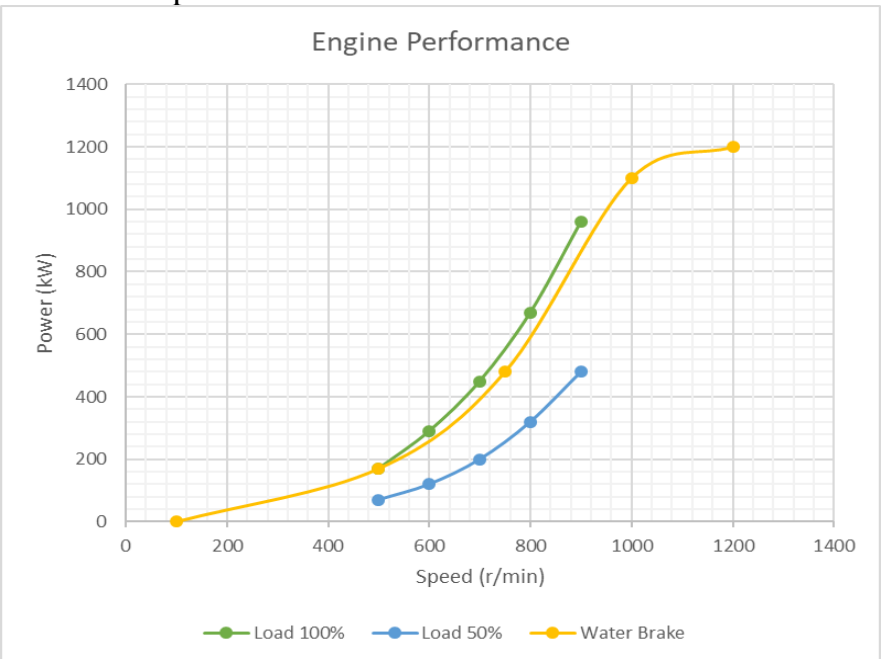

Figure. 3. Main Engine \& Water Brake Performance 
International Journal of Marine Engineering Innovation and Research, Vol. 1(4), Sept. 2017. 284-294 (pISSN: 2541-5972, eISSN: 2548-1479)

Source: Laboratory Building of the Maritime Department of Hochschule Wismar

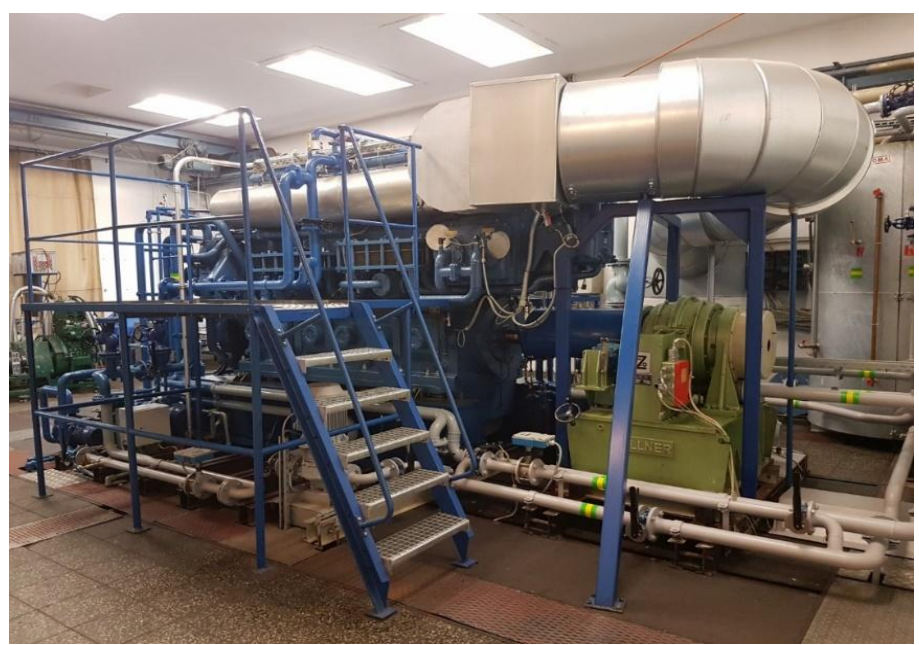

Figure. 4. MAN B\&W 6L23/30A

Source: Laboratory Building of the Maritime Department of Hochschule Wismar

TABLE. 1.

MAN B\&W 6L23/30A BASIC DATA

Engine Data

\begin{tabular}{|c|c|c|}
\hline \\
\hline Category & Content & Unit \\
\hline Manufacture & MAN B\&W & \\
\hline Type & $6 \mathrm{~L} 23 / 30 \mathrm{~A}$ & \\
\hline Cylinder & 6-4 stroke & \\
\hline Power & 960 & $\mathrm{~kW}$ \\
\hline Power/cyllinder & 160 & $\mathrm{~kW}$ \\
\hline Speed & 900 & $\mathrm{r} / \mathrm{min}$ \\
\hline Stroke & 300 & $\mathrm{Mm}$ \\
\hline Bore & 225 & $\mathrm{Mm}$ \\
\hline Stroke/bore & 1.33 & Ratio \\
\hline Compression & 12.5 & Ratio \\
\hline SFOC & 194 & $\mathrm{gr} / \mathrm{kWh}$ \\
\hline SLOC & 1 & $\mathrm{gr} / \mathrm{kWh}$ \\
\hline Dry mass & 11 & Ton \\
\hline
\end{tabular}

TABLE. 2.

ZOLLNER 9N38/12F BASIC DATA

Water Brake Data

\begin{tabular}{lll}
\multicolumn{1}{c}{ Category } & \multicolumn{1}{c}{ Content } & Unit \\
\hline Manufacture & Zollner & \\
Type & $9 \mathrm{~N} 38 / 12 \mathrm{~F}$ & \\
Power & 1200 & $\mathrm{~kW}$ \\
Speed & 3500 & $\mathrm{r} / \mathrm{min}$ \\
Torque & 7161 & $\mathrm{Nm}$ \\
Flow & 25 & $\mathrm{~m}^{3} / \mathrm{h}$ \\
\hline
\end{tabular}




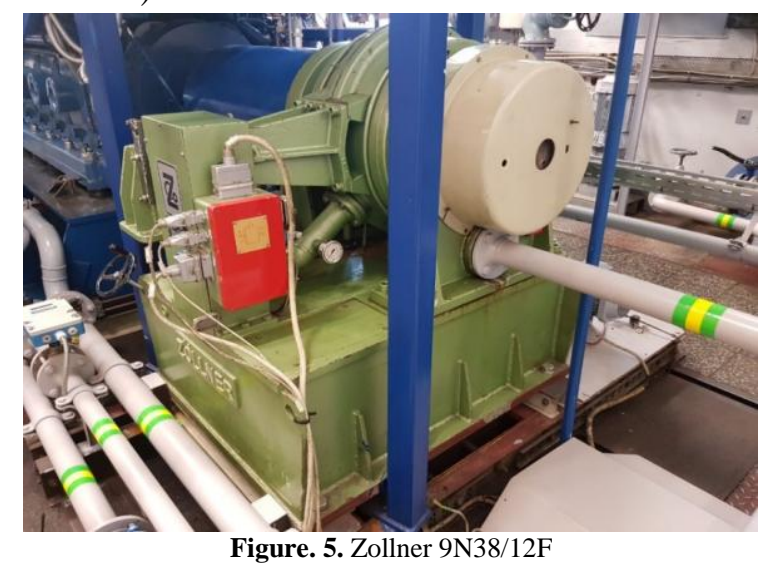

Source: Laboratory Building of the Maritime Department of Hochschule Wismar

TABLE. 3.

ENGINE PERFORMANCE

\begin{tabular}{cccc}
\multirow{4}{*}{ Load } & Axis (Y) & Axis (X) & Axis (Y) \\
\cline { 2 - 4 } & Torque & Speed & Power \\
\hline \% & Nm & r/min & kW \\
\hline $0 \%$ & 0 & 0 & 0 \\
$10 \%$ & 2196 & 417.7 & 96 \\
$20 \%$ & 3485 & 526.3 & 192 \\
$30 \%$ & 4567 & 602.5 & 288 \\
$40 \%$ & 5533 & 663.1 & 384 \\
$50 \%$ & 6420 & 714.3 & 480 \\
$60 \%$ & 7250 & 759.1 & 576 \\
$70 \%$ & 8035 & 799.1 & 672 \\
$80 \%$ & 8782 & 835.5 & 768 \\
$90 \%$ & 9500 & 868.9 & 864 \\
$100 \%$ & 10191 & 900 & 960 \\
\hline
\end{tabular}

\section{B. Data Variations}

The next step is make some variations data. I make some variations data regarding to visualization from the data block of PLC in Laboratory Building (House 2) of the Maritime Department of Hochschule Wismar.

First thing I have to do is open the file in the data block of PLC. And then look the address about the

After stored the address and value into my PLC program. I transfer the load characteristics (characteristic points) from visualization, I make some calculation of the intermediate values by interpolation to get some variations data for various load states. For this calculation using this formula:

$\mathrm{Y}=\mathrm{Y} 1+((\mathrm{X}-\mathrm{X} 1) /(\mathrm{X} 2-\mathrm{X} 1) \times(\mathrm{Y} 2-\mathrm{Y} 1)$

$\mathrm{X}$ is the value I set in my PLC program. In this case I set the speed value to get the actual power. Actual power is $\mathrm{Y}$ in this formula. The value of $\mathrm{X} 1$ is the lower value of speed than the value of $X$. The value of $X 2$ is the bigger value of speed than the value of $X$. So, the value of $X$ is located between $X 1$ and $X 2$. The value of $X 1$ and $\mathrm{X} 2$ is regarding to the table (see table 3 ).

The value of $\mathrm{Y} 1$ is the lower value of power than the value of $Y$. The value of $Y 2$ is the bigger value of power than the value of $\mathrm{Y}$. So, the value of $\mathrm{Y}$ is located between $\mathrm{Y} 1$ and $\mathrm{Y} 2$. The value of $\mathrm{Y} 1$ and $\mathrm{Y} 2$ is power and the speed of the engine. I save every address for every load, from $0 \%$ of load until $100 \%$ of load in my PLC program. After that stored the value that I got from Laboratory Building (House 5) of the Maritime Department of Hochschule Wismar into my PLC program. And this is the data I make in my PLC program shown in table 3.

regarding to the table (see table 3 ). The $X$ axis is speed of engine and the $\mathrm{Y}$ axis is the power of engine.

For example, if I want to get the power between load $10 \%$ and load $20 \%$ so for example I set the value of actual speed in the $450 \mathrm{rpm}$. The value of X1 is 417,7 (load 10\%) and the value of X2 is 526,3 (load 20\%). The value of $\mathrm{Y} 1$ is $96 \mathrm{~kW}(\operatorname{load} 10 \%)$ and the value of $\mathrm{Y} 2$ is $192 \mathrm{~kW}$ (load 20\%). Regarding to the formula, so we can get the value of actual power is $124 \mathrm{~kW}$. This value is located between load $10 \%$ and load $20 \%$ of engine power.

After I make some interpolation calculation using that formula I make some various load states (see table 4) and then, make the diagram to show the various load states using interpolation (see figure 6). To make the diagram easy to read so I make two diagrams and to make comparison every load. First diagram is Variations Interpolation Between Power and Time (see figure 7). Second diagram is Variations Interpolation Between Speed and Time (see figure 8). I choose time for variable comparison because time prove it. I make diagram for 
every 100 second per interpolation off percentage load states. For example, in the $10 \%$ of load in 100 second produce more power in a longer time than $20 \%$ of load.
And then, make some comparison between power, speed and torque shown in figure 9 .

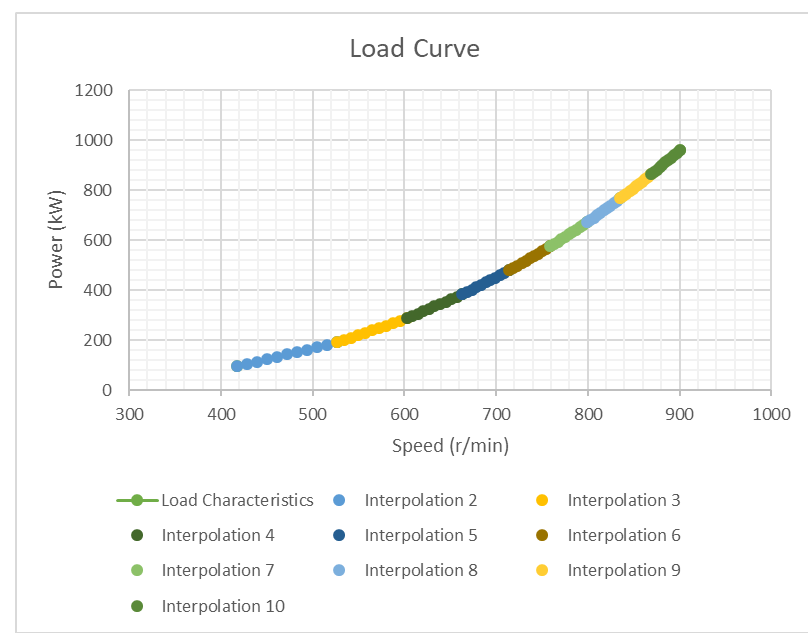

Figure. 6. Load Curve

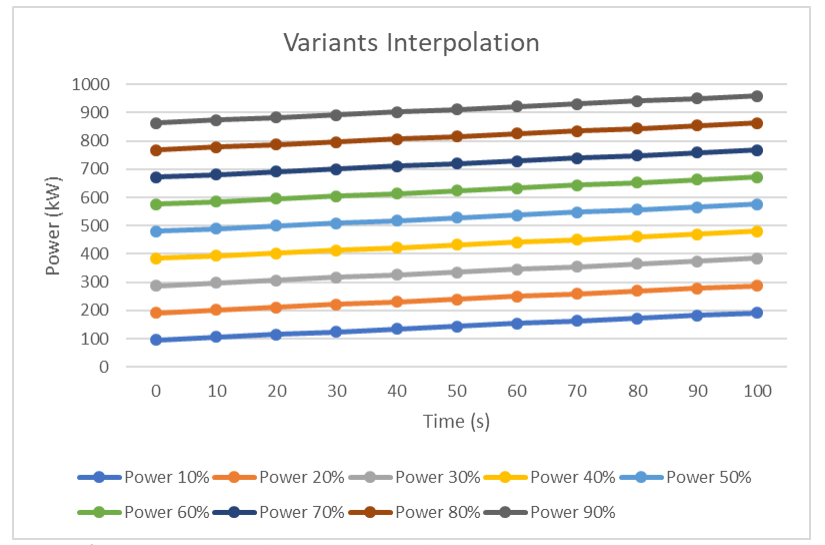

Figure. 7. Variations Interpolation Between Power and Time

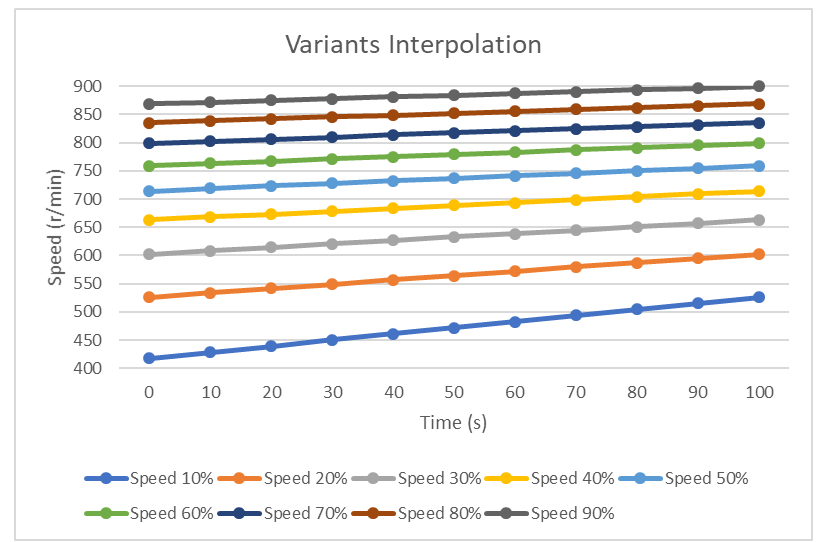

Figure. 8. Variations Interpolation Between Speed and Time 
International Journal of Marine Engineering Innovation and Research, Vol. 1(4), Sept. 2017. 284-294 (pISSN: 2541-5972, eISSN: 2548-1479)

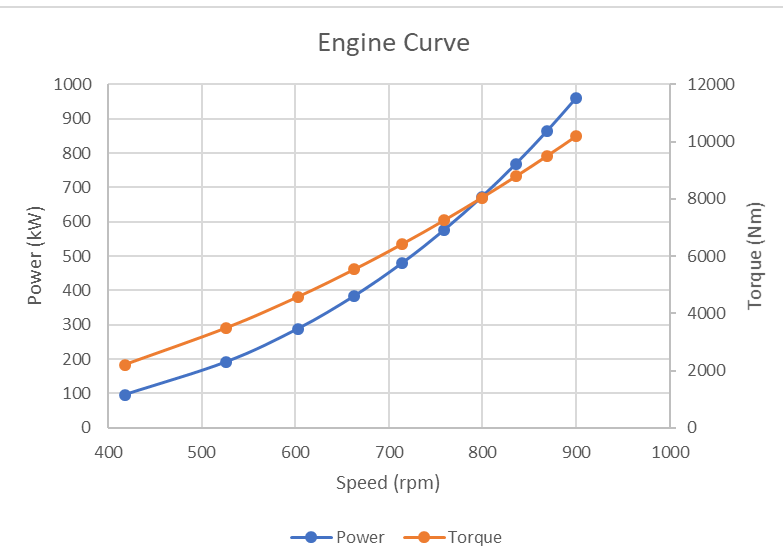

Figure. 9. Engine Curve Between Power, Speed and Torque

TABLE. 4 .

INTERPOLATION CALCULATION Injection

\begin{tabular}{|c|c|c|c|c|c|c|c|c|c|c|c|c|c|c|c|c|c|c|c|c|}
\hline \multirow{3}{*}{$\begin{array}{c}\text { Time } \\
\text { t/s }\end{array}$} & \multicolumn{20}{|c|}{ Injection } \\
\hline & \multicolumn{2}{|c|}{1} & \multicolumn{2}{|c|}{2} & \multicolumn{2}{|c|}{3} & \multicolumn{2}{|c|}{4} & \multicolumn{2}{|c|}{5} & \multicolumn{2}{|c|}{6} & \multicolumn{2}{|c|}{7} & \multicolumn{2}{|c|}{8} & \multicolumn{2}{|c|}{9} & \multicolumn{2}{|c|}{10} \\
\hline & $\begin{array}{l}\begin{array}{l}\text { Axis } \\
(\mathbf{X})\end{array} \\
\end{array}$ & $\begin{array}{l}\text { Axis } \\
\text { (Y) }\end{array}$ & $\begin{array}{l}\begin{array}{l}\text { Axis } \\
(\mathbf{X})\end{array} \\
\end{array}$ & $\begin{array}{l}\text { Axis } \\
\text { (Y) }\end{array}$ & $\begin{array}{l}\begin{array}{l}\text { Axis } \\
(\mathbf{X})\end{array} \\
\end{array}$ & $\begin{array}{l}\text { Axis } \\
\text { (Y) }\end{array}$ & $\begin{array}{l}\text { Axis } \\
(\mathbf{X}) \\
\end{array}$ & $\begin{array}{l}\text { Axis } \\
\text { (Y) }\end{array}$ & $\begin{array}{l}\begin{array}{l}\text { Axis } \\
(\mathbf{X})\end{array} \\
\end{array}$ & $\begin{array}{c}\text { Axis } \\
(\mathbf{Y})\end{array}$ & $\begin{array}{l}\text { Axis } \\
\text { (X) }\end{array}$ & $\begin{array}{c}\text { Axis } \\
(\mathbf{Y})\end{array}$ & $\begin{array}{l}\text { Axis } \\
\text { (X) }\end{array}$ & $\begin{array}{l}\text { Axis } \\
\text { (Y) }\end{array}$ & $\begin{array}{l}\text { Axis } \\
(\mathbf{X})\end{array}$ & $\begin{array}{l}\text { Axis } \\
(\mathbf{Y})\end{array}$ & $\begin{array}{l}\text { Axis } \\
(\mathbf{X})\end{array}$ & $\begin{array}{l}\text { Axis } \\
\text { (Y) }\end{array}$ & $\begin{array}{l}\text { Axis } \\
(\mathbf{X})\end{array}$ & $\begin{array}{c}\text { Axis } \\
(\mathbf{Y})\end{array}$ \\
\hline 0 & 0 & 0 & 417,7 & 96 & 526,3 & 192 & 602,5 & 288 & 663,1 & 384 & 714,3 & 480 & 759,1 & 576 & 799,1 & 672 & 835,5 & 768 & 868,9 & 864 \\
\hline 10 & 41,77 & 9,6 & 428,56 & 105,6 & 533,92 & 201,6 & 608,56 & 297,6 & 668,22 & 393,6 & 718,78 & 489,6 & 763,1 & 585,6 & 802,74 & 681,6 & 838,84 & 777,6 & 872,01 & 873,6 \\
\hline 20 & 83,54 & 19,2 & 439,42 & 115,2 & 541,54 & 211,2 & 614,62 & 307,2 & 673,34 & 403,2 & 723,26 & 499,2 & 767,1 & 595,2 & 806,38 & 691,2 & 842,18 & 787,2 & 875,12 & 883,2 \\
\hline 30 & 125,31 & 28,8 & 450,28 & 124,8 & 549,16 & 220,8 & 620,68 & 316,8 & 678,46 & 412,8 & 727,74 & 508,8 & 771,1 & 604,8 & 810,02 & 700,8 & 845,52 & 796,8 & 878,23 & 892,8 \\
\hline 40 & 167,08 & 38,4 & 461,14 & 134,4 & 556,78 & 230,4 & 626,74 & 326,4 & 683,58 & 422,4 & 732,22 & 518,4 & 775,1 & 614,4 & 813,66 & 710,4 & 848,86 & 806,4 & 881,34 & 902,4 \\
\hline 50 & 208,85 & 48 & 472 & 144 & 564,4 & 240 & 632,8 & 336 & 688,7 & 432 & 736,7 & 528 & 779,1 & 624 & 817,3 & 720 & 852,2 & 816 & 884,45 & 912, \\
\hline 60 & 250,62 & 57,6 & 482,86 & 153,6 & 572,02 & 249,6 & 638,86 & 345,6 & 693,82 & 441,6 & 741,18 & 537,6 & 783,1 & 633,6 & 820,94 & 729,6 & 855,54 & 825,6 & 887,56 & 921,6 \\
\hline 70 & 292,39 & 67,2 & 493,72 & 163,2 & 579,64 & 259,2 & 644,92 & 355,2 & 698,94 & 451,2 & 745,66 & 547,2 & 787,1 & 643,2 & 824,58 & 739,2 & 858,88 & 835,2 & 890,67 & 931,2 \\
\hline 80 & 334,16 & 76,8 & 504,58 & 172,8 & 587,26 & 268,8 & 650,98 & $\begin{array}{l}364,8 \\
\end{array}$ & 704,06 & 460,8 & 750,14 & 556,8 & 791,1 & 652,8 & 828,22 & 748,8 & 862,22 & 844,8 & 893,78 & 940,8 \\
\hline 90 & 375,93 & 86,4 & 515,44 & 182,4 & 594,88 & 278,4 & 657,04 & 374,4 & 709,18 & 470,4 & 754,62 & 566,4 & 795,1 & 662,4 & 831,86 & 758,4 & 865,56 & 854,4 & 896,89 & 950,4 \\
\hline 100 & 417,7 & 96 & 526,3 & 192 & 602,5 & 288 & 663,1 & 384 & 714,3 & 480 & 759,1 & 576 & 799,1 & 672 & 835,5 & 768 & 868,9 & 864 & 900 & 960 \\
\hline
\end{tabular}

TABLE. 5.

LOAD CHARACTERISTIC

\begin{tabular}{|c|c|c|c|c|c|c|c|c|c|c|c|}
\hline \multirow[b]{2}{*}{. Load } & \multirow{2}{*}{$\begin{array}{c}\text { Axis (X) } \\
\text { Speed }\end{array}$} & \multicolumn{10}{|c|}{ Axis (Y) } \\
\hline & & \multicolumn{10}{|c|}{ Power } \\
\hline \multirow{2}{*}{$\%$} & \multirow{2}{*}{$\mathrm{r} / \mathrm{min}$} & \multicolumn{10}{|c|}{$\mathbf{k W}$} \\
\hline & & $100 \%$ & $90 \%$ & $80 \%$ & $70 \%$ & $60 \%$ & $\mathbf{5 0 \%}$ & $40 \%$ & $30 \%$ & $20 \%$ & $10 \%$ \\
\hline 0 & 0 & 0 & 0 & 0 & 0 & 0 & 0 & 0 & 0 & 0 & 0 \\
\hline 10 & 417,7 & 96 & 86,4 & 76,8 & 67,2 & 57,6 & 48 & 38,4 & 28,8 & 19,2 & 9,6 \\
\hline 20 & 526,3 & 192 & 172,8 & 153,6 & 134,4 & 115,2 & 96 & 76,8 & 57,6 & 38,4 & 19,2 \\
\hline 30 & 602,5 & 288 & 259,2 & 230,4 & 201,6 & 172,8 & 144 & 115,2 & 86,4 & 57,6 & 28,8 \\
\hline 40 & 663,1 & 384 & 345,6 & 307,2 & 268,8 & 230,4 & 192 & 153,6 & 115,2 & 76,8 & 38,4 \\
\hline 50 & 714,3 & 480 & 432 & 384 & 336 & 288 & 240 & 192 & 144 & 96 & 48 \\
\hline 60 & 759,1 & 576 & 518,4 & 460,8 & 403,2 & 345,6 & 288 & 230,4 & 172,8 & 115,2 & 57,6 \\
\hline 70 & 799,1 & 672 & 604,8 & 537,6 & 470,4 & 403,2 & 336 & 268,8 & 201,6 & 134,4 & 67,2 \\
\hline 80 & 835,5 & 768 & 691,2 & 614,4 & 537,6 & 460,8 & 384 & 307,2 & 230,4 & 153,6 & 76,8 \\
\hline 90 & 868,9 & 864 & 777,6 & 691,2 & 604,8 & 518,4 & 432 & 345,6 & 259,2 & 172,8 & 86,4 \\
\hline 100 & 900 & 960 & 864 & 768 & 672 & 576 & 480 & 384 & 288 & 192 & 96 \\
\hline
\end{tabular}




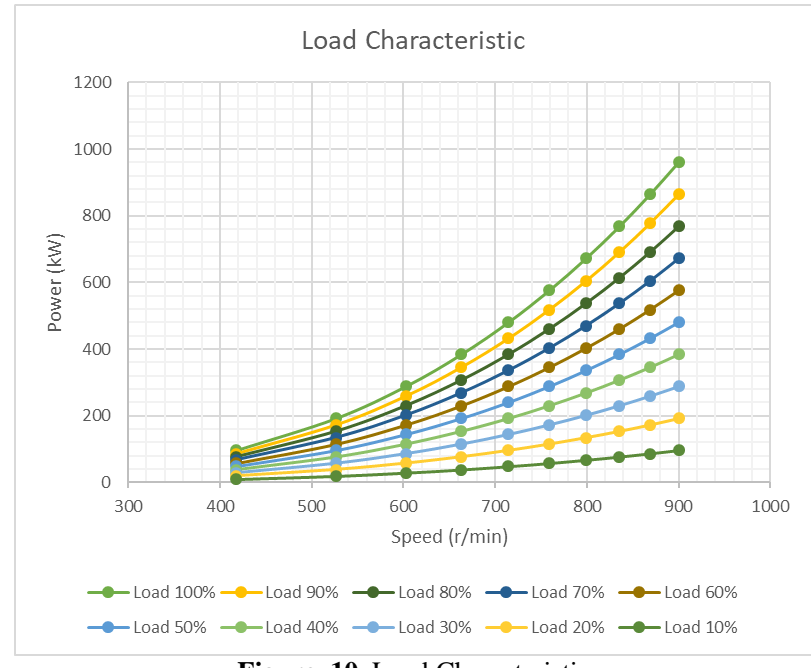

Figure. 10. Load Characteristic

Regarding the data I got from Laboratory Building (House 5) of the Maritime Department of Hochschule Wismar shown in figure 3 . The maximum capacity that can be produce from water brake is $90 \%$ of load. So, I can make some comparison producing power use water brake to give load to the main engine (see table 5). For example, if I setup water brake in $10 \%$ of load we get the power in table $10 \%$ of power. And I make comparison of main engine from $10 \%$ of power until $100 \%$ of power shown in figure 10.

\section{PLC Programming}

After got the data from visualization and make some variations data using interpolation. The final step is programming and storing of the load characteristics in the PLC. Before I can store the load characteristics, I have to make the program.

The first thing I have to do is add the hardware. And then add the rack rail to make a slot to input the PS (power supply) and CPU (Central Processing Unit). I choose PS 307 5A and CPU 313C DI24/DO16 AI5/AO6. Because the device in the Laboratory Building (House 2) of the Maritime Department of Hochschule Wismar using that device.

After I add the PS and CPU I have to connect the computer and the device with make the same IP address between the computer and the device. Before I make the same IP address I have to input ethernet to the slot in the rack rail. I choose CP 343-1 for the ethernet. After I add the hardware and connect the computer with the hardware, I can start to make the symbols which will be used in my program.

After finish to make all of symbols to use in the program, so I can start to make the all of function to make the program works. First thing I have to do is make OB1. OB1 is the main program. All of function will save and call in the OB1. In the OB1 I have all of function which will be used to make the program works.

After that I make all of function which is contained all of input, output, and memory. In the FC1 I insert all of input I will use in my program like engine button on and off, stop button and emergency stop button. In the FC2 I make all of memory about engine operation like engine will be turn on if I turn on the engine button on. The engine will be turn off if I turn off the engine button off.
In the FC3 I make all of memory about power operation of engine. In the FC4 I make all of memory about speed operation of engine. In the FC6 I insert all of output I will use in my program like the engine turn on and the alarm will be turn on if the engine in the over speed condition. That function will be use if the PLC program is connected with the visualization program which have all of the button and the visualization interface.

In the FC5 I make all of calculation to decide the input of set value get into which range. For the example if we set the value in $450 \mathrm{rpm}$, the input will be get into range 1 . Because the value of range 1 is between 418 rpm (load 10\%) until 526 rpm (load 20\%).

After I input some set value of speed and the FC5 decide the set value of speed get into which range. The output is will be jump to another function (FC101FC109). In the FC101-FC109 I make all of calculation for every range (range 1-9). Range 1 is between load $10 \%$ - load $20 \%$ and so on. For the example, after input the set value of speed in the $450 \mathrm{rpm}$ FC5 will be decide this value get into FC101. Because in FC101 I make all of calculation to make the set value of power using interpolation formula. The value which is used in the interpolation formula regarding to reference value.

And then the output of FC101-FC109 to show the result for interpolation calculation. For example, is the input is $450 \mathrm{rpm}$ (actual value of speed) so the output is $124 \mathrm{~kW}$ (actual value of power). The speed input in the visualization is just for the test, I must use the Input from the speed interface. For the visualization (see figure 11).

The reference value of power I save in the DB7 and reference value of speed I save in the DB6. And the result for all of calculation I save in the DB5. In DB4 I can change the percentage of water brake load. For example, if I set the percentage of water brake load in the $100 \%$. The input value of speed is $418 \mathrm{rpm}$ so the value of power is $96 \mathrm{~kW}$. But if I set the percentage of load water brake in the $90 \%$. So, the value of power will be decrease into $86 \mathrm{~kW}$.

In the FC7 I make all of function to move the reverence value of power from DB3 into DB7 to make visualization. In the FC8 I make all of function to move the reverence value of speed from DB4 into DB6 to make visualization. This purpose if $I$ change the reference value of power and speed, in the visualization 
no problem will occur. After that, activated the take-over

the new value.

button to change the value in visualization before into

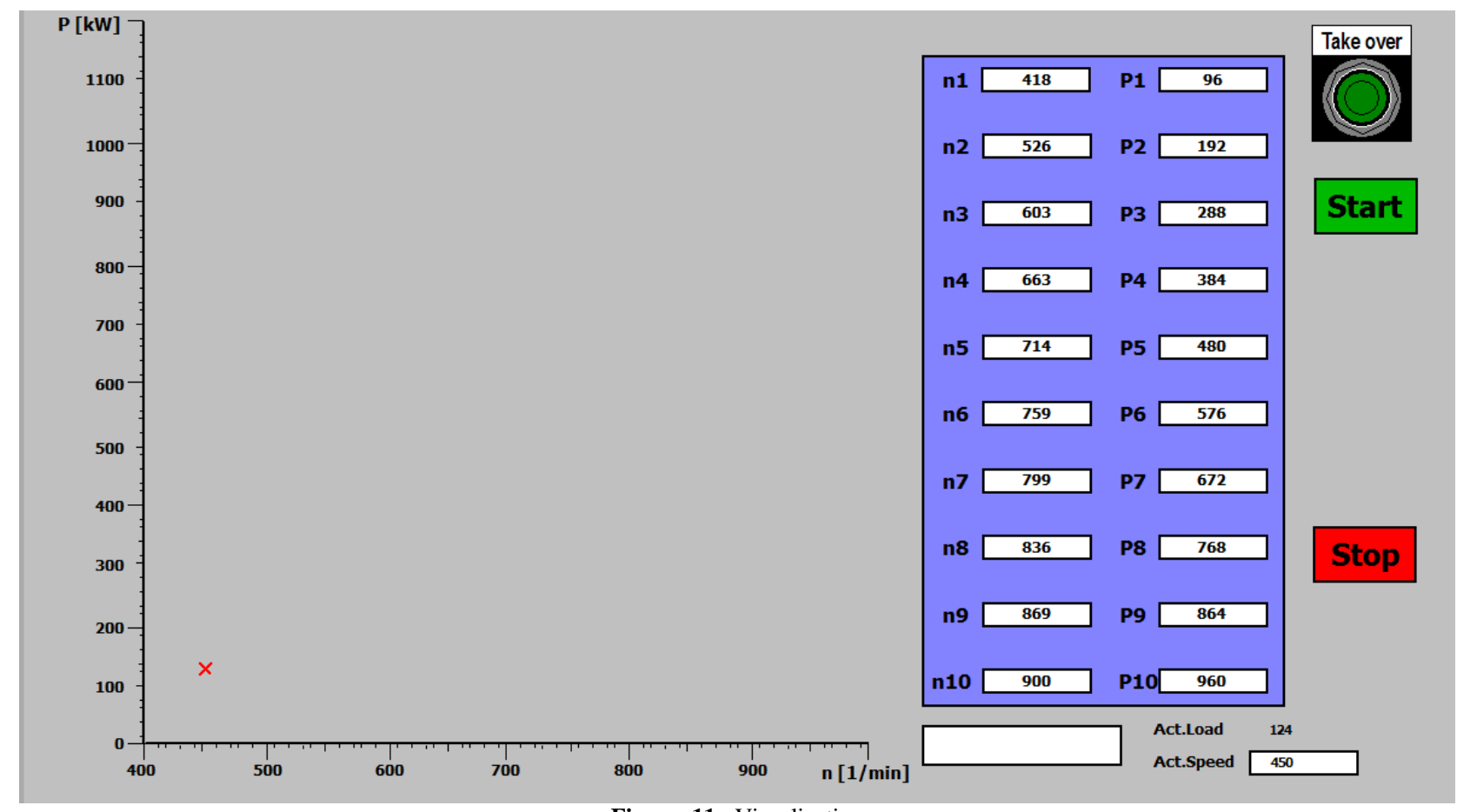

Figure. 11.: Visualization

Before I can run using the device (online) I can run using simulation (offline). And then before simulated the program I have to download all of the function into simulation. After that to check the program is works using RUN-P. EB is input Bits and $\mathrm{AB}$ is output in Bits.
The address is 124 because I have to match the address with the hardware. MB is the memory in Bits. $\mathrm{T}$ is timer and $\mathrm{Z}$ is counter (see figure 12). For the hardware (see figure 13). for the function (see figure 14).

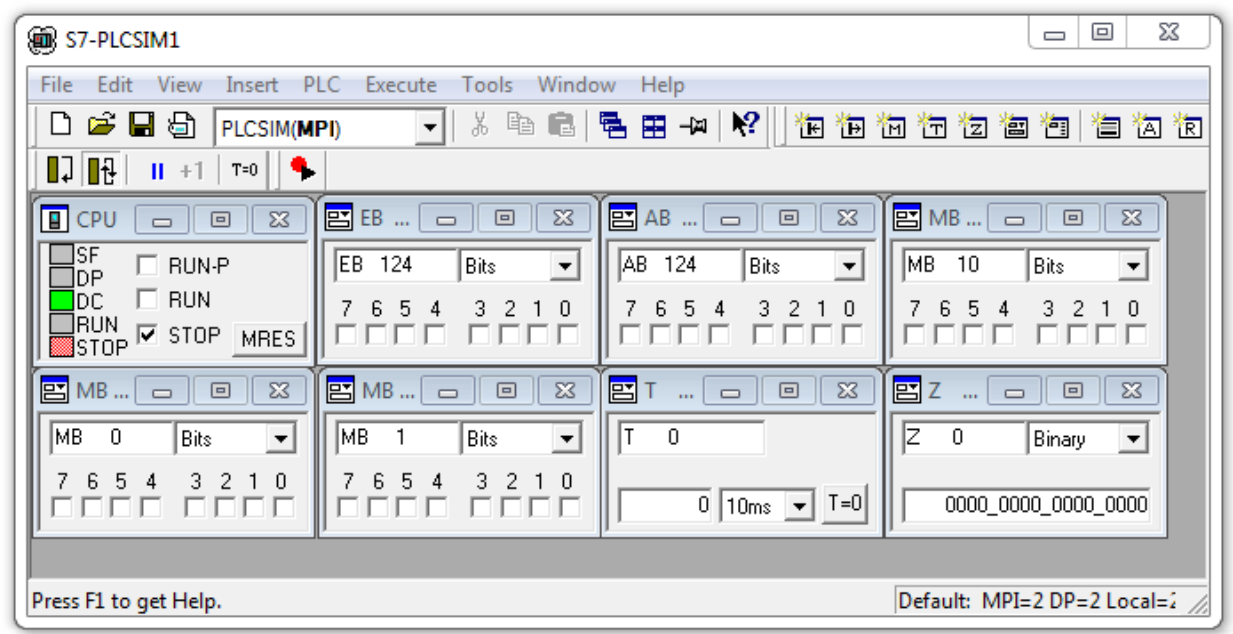

Figure. 12. Simulation 


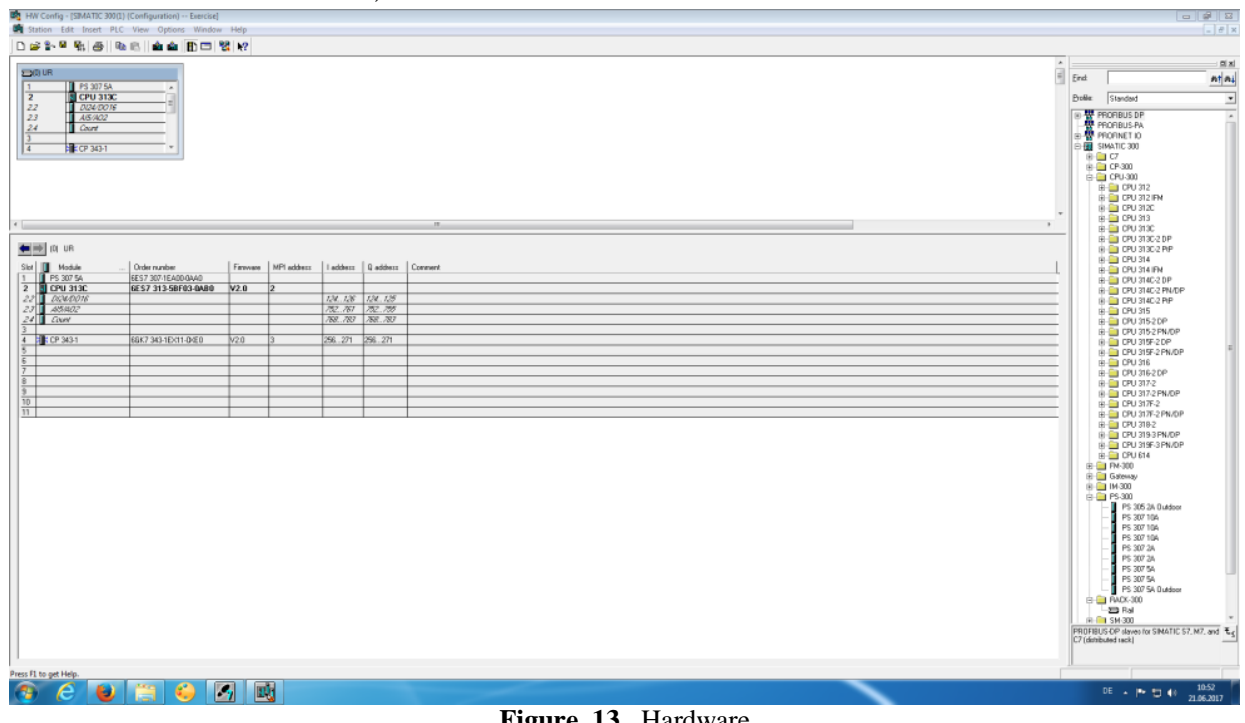

Figure. 13. Hardware

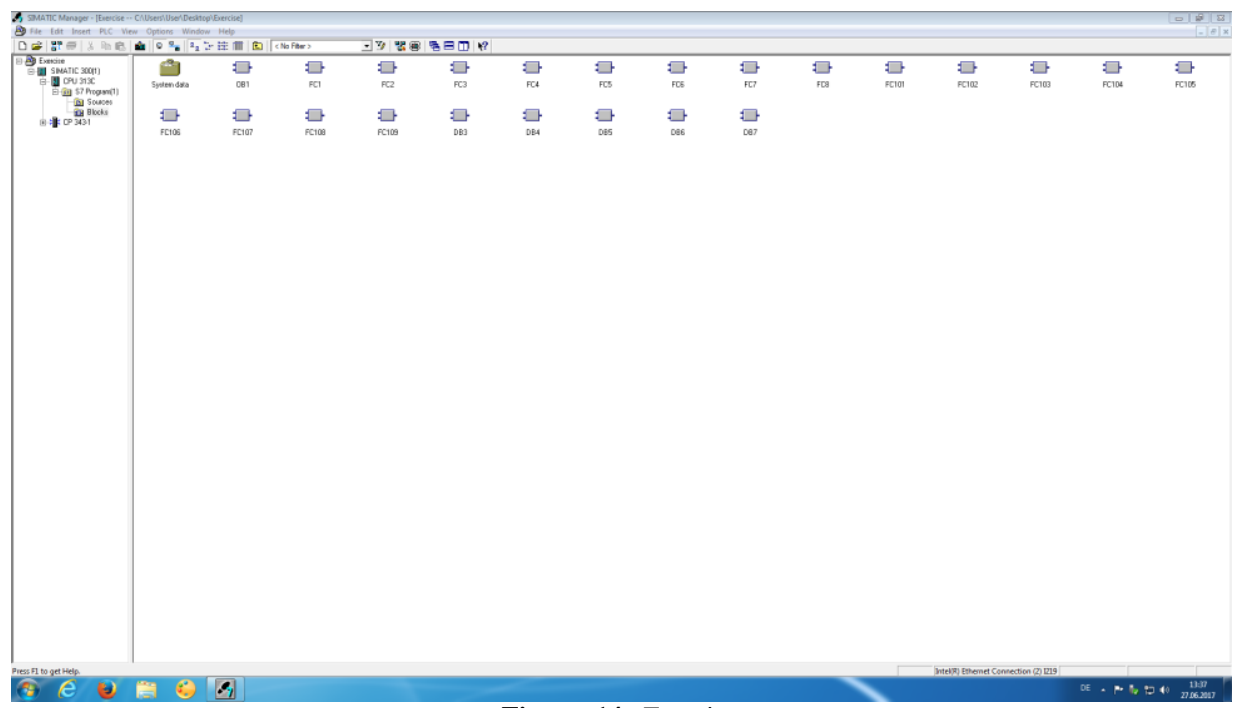

Figure. 14. Function

\section{CONCLUSION}

On this day, PLC can solve many problems in various fields. All systems that are in all places are almost compatible with PLC. For the examples such as in buildings, public transportation, industry and so forth. You should also realize that right now, if you had a PLC and enough ladder logic knowledge you could construct a sophisticated machine with little problem as far as operational logic is concerned.

PLC are flexible and can be reapplied to control other systems quickly and easily. They are cost effective for controlling complex systems. They possess high computational ability that allows more sophisticated control through ladder logic. Trouble shooting aids make programming easier and reduce downtime. Reliable components make PLCs likely to operate for years before failure.

With a variety of basic functions of existing programming can be made a useful program. This program can be connected to the device. Where this program can run a visualization to show load characteristics of the engine. How its work is give the set value of speed and we will get the actual value of power. It is obtained from the calculation of interpolation that everything is done automatically by PLC program that has been made.

Regarding to the diagram that already made (see figure 6, 7 and 8), we know the characteristic of the engine. In the low rpm to reach the set value rpm need a lot of time than to reach the set value rpm in the high rpm. I choose time for variable comparison because time prove it.

So, the function of dynamometer (water brake) is a load device which is generally used for measuring the power output of an engine. And to make water brake give load to the engine we don't use hand. But we use automatic system (PLC) with operator.

The aim of this research to analysis of possible load states of the main engine which can be provided by the water break is complete realized (see figure 10 and table 5). And then to make the PLC compatible is complete realized use test (see figure $11 \& 12$ ). And for the calculation of interpolation to get intermediate value is complete realized (see table 4).

\section{ACKNOWLEDGEMENT}

Thanks to Laboratory Building of the Maritime Department of Hochschule Wismar for contributing in License of original SIEMENS SIMATIC MANAGER Software. 


\section{REFERENCES}

[1] Water Brake Dynamometers. Switzerland: 2013. Phenix Technologies.

[2] Toepfer, Josiah: What Kind of Engines are Used in Big Ships. www.quora.com (2015)

[3] The Marine Diesel Propulsion System. 2002. Robust Control of Diesel Ship Propulsion.

[4] Application Note AC Synchronous Generator. Tampa, Florida. PdMA Corporation.

[5] Manney, David: Breaking Down the Difference Between AC and DC Generators. www.lselectric.com (2015)

[6] Bolotinha, Manuel: Basic Theory of Generators. www.linkedin.com (2016)

[7] Gitano, Horizon: Dynamometer Basics. University Science Malaysia, 2008

[8] Odesie: Programmable Logic Controller (PLC). www.myodesie.com

[9] Laboratory Exercises of Process Engineering Programmable Logic Controller in a dosing process. University of Oulu, Department of Process and Environmental, Engineering Systems Engineering Laboratory, 2013

[10] Kaushal, Neha: Role of PLC in Automation and its Various Applications. Department of Electrical Engineering, Bhutta Group of Institutions, Punjab, India, 2015

[11] SCE Training Curriculum for Integrated Automation Solution Totally Integrated Automation (TIA). TIA Portal Modul, 2013. Siemens.

[12]Tanoto, Eko Wahyu: Programmable Logic Controller. www.tanotocentre.wordpress.com (2010)

[13]Quick Start Manual Vipa CPU 313SC. Herzogenaurach: 2008. VIPA.

[14]Kulkarni, Pradnya \& Kadu, Chandrakant: PID Based Dynamometer Used in Engine Test. (2015)

[15]Lish, Tom: What is a Dynamometer and how does it work. www.setra.com/blog/test-and-measurement-dynamometer (2015)

[16]Semin., A.R. Ismail., T.F. Nugroho., 2010. Experimental and Computational of Engine Cylinder Pressure Investigation on the Port Injection Dedicated CNG Engine Development. Journal of Applied Sciences 10 (2).

[17]Semin., A.R. Ismail., R.A. Bakar., 2009. Gas Fuel Spray Simulation of Port Injection Compressed Natural Gas Engine Using Injector Nozzle Multi Holes. European Journal of Scientific Research 29 (2), 188-193

[18] Semin., A.R. Ismail., R.A. Bakar., 2009. Effect of diesel engine converted to sequential port injection compressed natural gas engine on the cylinder pressure vs Crank angle in variation engine speeds. American Journal of Engineering and Applied Sciences 2 (1), 154-159.

[19] Semin., R.A. Bakar., A.R. Ismail., 2009. Compressed Natural Gas as an Alternative Fuel for Internal Combustion Engines: a Technical Review. International Review of Mechanical Engineering 3 (2), 188-195

[20] Semin., A.R. Ismai.l, R.A. Bakar., 2009. Investigation of torque performance effect on the development of sequential injection CNG engine. Journal of Applied Sciences 9 (13), 2416-2423

[21]Semin., R.A. Bakar., A.R. Ismail., 2009. Green engines development using compressed natural gas as an alternative fuel: A review. American Journal of Environment Sciences 5, 371-381

[22] Gitano, Horizon: Dynamometer Basics. University Science Malaysia, Malaysia2008.

[23] Kaushal, Neha: Role of PLC in Automation and its Various Applications. Department of Electrical Engineering, Bhutta Group of Institutions, Punjab, India, 2015

[24] Siemens., SCE Training Curriculum for Integrated Automation Solution Totally Integrated Automation (TIA). TIA Portal Modul, 2013. Siemens.

[25] Semin, Iswantoro A., Faris F. "Performance and NOx Investigation on Diesel Engine using Cold EGR Spiral Tube: A Review." International Journal of Marine Engineering Innovation and Research., vol. 1, no. 3, Jun. 2017

[26] Zuhdi A., Busse W., Clausthaldi. "Fluid Flow Analysis of Jacket Cooling System for Marine Diesel Engine 93 KW". International Journal of Marine Engineering Innovation and Research., vol. 1, no. 2, Mar. 2017 